\title{
DEMOKRASI CIVIL SOCIETY DI INDONESIA DAN INDIA: SEBUAH PERBANDINGAN
}

\author{
Gemael Flamirion dan Muradi \\ Departemen Ilmu Politik, Universitas Padjadjaran \\ E-mail: muradiclark@gmail.com
}

\begin{abstract}
ABSTRAK
Indonesia dan India merupakan dua negara dengan kemiripin geografis, demografis dan historis. Proses demokratisasi kemudian mengakselarasi pembangunan sektor civil society di kedua negara ini. Fenomena demokratisasi dan pembangunan civil society di kedua negara ini menarik untuk dikaji dari prespektif perbandingan politik. Tulisan ini bertujuan mendeskripsikan dengan mendalam mengenai proses demokratisasi dan pembangunan civil society dikedua negara ini, sehingga nantinya dapat dibandingkan dalam tataran teori dan realitas.
\end{abstract}

Kata kunci: Demokratisasi, Civil society, Perbandingan politik

\section{DEMOCRACY AND CIVIL SOCIETY IN INDONESIA AND INDIA: A COMPARISON STUDY}

\begin{abstract}
Indonesia and India are two countries with similiarities in geographic, demographic and historical. The democratization process accelerates the development of civil societies sector in these countries. Democratization phenomena and development of civil society in both countries are interesting object to be studied in the perspective of comparative politics. This paper aims to accurately describe democratization procces and the development of civil society in both countries, so it can be compared at the level of theory and reality.
\end{abstract}

Key words: Democratization, civil society, comparative politics

\section{PENDAHULUAN}

Dalam dua dekade terakhir civil society menjadi pembahasan yang populer dalam kajian ilmu-ilmu sosial sebagai hal yang dianggap menempati ruang antara dalam hubungan negara dan individu. Jika melihat dari prespektif kebahasaan, dalam bahasa Indonesia civil society biasanya dipadankan dengan masyarakat madani, yang secara pengertian mengacu pada sifat-sifat masyarakat Kota Madinah dibawah kepemimpinan Nabi Muhammad. Penulis sendiri lebih sepakat untuk menggunakan istilah masyarakat sipil sebagai padanan kata untuk frasa ini dalam Bahasa Indonesia, sebab secara pengertian kebahasaan istilah inilah yang paling mendekati arti dari civil society secara umum. Selain itu, penggunaan istilah masyarakat sipil akan lebih akan lebih akurat dalam menggambarkan bentuk sesungguhnya dari civil society yang terkait dengan konsep demokrasi yang bersifat sekuler (terpisah dari dogma-dogma agama).

Baik demokrasi (yang kemudian menurunkan demokratisasi) atau civil society dalam wacana keilmuan dipandang sebagai konsepkonsep yang bersifat elusive. Konsep-konsep mengenai kedua hal ini bersifat dinamis dan bergantung pada banyak variabel, seperti dimana dan kapan berkembangnya, atau siapa yang melakukan pendefinisian konsep tersebut. Meskipun begitu, pada umumnya para akademisi ilmu sosial berpendapat bahwa civil society dalam bentuk yang ideal merupakan konsekuensi dari keberadaan pemerintahan dan masyarakatyang demokratis. Pemerintahanyang demokratis idealnya dapat menciptakan ruang berinteraksi dan berorganisasi bagi individu secara bebas yang nantinya akan mendorong masyarakat sipil sebagai sebuah organisasi atau gerakan. Dalam kondisi ini, menurut prespektif 
natural civil society, keberadaan civil society dipandang sebagai sesuatu yang natural, tercipt sebagai konsekuensi dari proses interaksi individu dalam ruang publik yang bebas dan dijamin oleh negara.

Indonesia adalah locus yang menarik untuk mengobservasi keberadaan dan perkembanga civil society. Bukan hanya karena Indonesia secara statistik merupakan salah satu negara demokratis terbesar didunia, melainkan juga karena faktor-faktor lain seperti heterogenitas rasial, konflik antar golongan atau ideologi yang dinamis dan sejarah pergolakan politik yang panjang. Verena Beittinger Lee dari Universitas Kent Inggris menulis buku berjudul (Un)Civil society and Political Change in Indonesia (2012) yang secara khusus membahas perkembangan civil society di Indonesia. Lee (2010) dalam bagian awal bukunya menganalogikan usah untuk menggambarkan perkembangan civil society di Indonesia seperti halnya dengan berusaha untuk menangkap angin. Wilayah geografis yang sangat luas, masyarakat yang sangat beragam, dan sejarah yang sangat panjang menjadi argumen pendukung yang disampaikan Lee terkait dengan analogi ini.

Secara sejarah, keberadaan civil society dapat dipandang lebih tua dari Indonesia sebaga negara bangsa yang berdiri 1945. Organisasiorganisasi masyarakat sipil seperti Budi Utomo, Serikat Dagang Islam perinat Dain memain peran tersendiri dalam perjuaangan kemerdekaa Hindia Belanda yang kemudian bertranformas menjadi Negara Kesatuan Republik Indonesia. Hari ini 71 tahun setelah kelahiran negara Indonesia dan 18 tahun setelah reformasi politik yang mendorong demokratisasi, civil society adalah topik yang menarik untuk dikaji. Dalam tulisan ini penulis akan mendeskripsikan sebaik mungkin bagaimana kondisi civil society di Indonesia dan keterkaitannya dengan proses demokratisasi dan kemudian membuat perbandingan dengan fenomena yang sama di India.

Setidaknya ada dua alasan utama India dipilih sebagai setting pembanding dalam tulisan ini. Pertama adalah kemiripin demografis dan sejarah. Baik Indonesia maupun India merupakan negara dengan populasi penduduk yang tinggi. Berdasarkan data yang dikeluarkan oleh worldometers, Indonesia dan India merupakan negara yang berada dalam lima besar penduduk terbanyak di dunia. Dengan jumlah penduduk sekitar 1,3 milyar manusia India menempati posisi dua dalam pemeringakatan ini, sedangkan Indonesia berada di posisi ke empat dengan 261 juta penduduk. Selain itu kedua menurut data yang dirilis geohive (dikutip dari www.geohive.com/earth/area_top50), juga dapa di kategorikan sebagi negara dengan wilayah geografis yang luas (India posisi tujuh dan Indonesia poisi lima belas). Kedua negara juga dikenal sebagai negara dengan karakteristik demografi yang bersifat multikultur dan multiras. Secara sejarah, India dan Indonesia juga memiliki kemiripan sebagai negara yang mencapa kemerdekaan dengan melakukan perlawanan terhadap kolonialisme. Hal ini membuat setting sosial politik di Indonesia dan India, dalam batasbatas tertentu, memiliki banyak kemiripan

Alasan kedua adalah kemiripan kondisi demokrasi, situasi politik dan civil society. Baik di Indonesia dan India, meskipun terus berusaha mendorong proses demokratisasi dan pembangunan civil society kearah yang lebih baik, meskipun hingga saat ini kondisi keduanya masih jauh dari ideal. Demokrasi di kedua negara ini berjuang menghadapi tantangantantangan yang tidak ringan, seperti konflik horizontal berbasis suku agama atau ras, kultur feodal yang masih kuat dan oligarki elit yang membebani sistem politik. Membandingkan demokratisasi dan civil society antara India Indonesia seperti melihat dua sisi mata uang, serupa tapi tidak sama.

\section{HASIL DAN PEMBAHASAN}

\section{Demokrasi dan Civil Society}

Pemikiran mengenai demokrasi dan masyarakat sipil telah ada sejak pemikiran politik barat modern mulai berkembang. Konsepkonsep awal mengenai kedua objek sama-sama merupakan produk pemikiran dari kebudayaan negara kota Athena. Solon, Socrates, Plato dan Aristoteles dikenal sebagai pemikir-pemiki pertama yang melahirkan konsep demokras sebagai bagian dari kajian filsafat politik yang populer ketika itu. Aristoteles kemudian memperkenalkan istilah koinonia politike yang seringkali dipandang sebagai konsep pertama yang mendefinisikan masyarakat sipil dalam konteks negara-kota. Selanjutnya kedua konsep berkembang dengan pesat, sejalan dengan perkembangan filsafat dan ilmu politik modern.
John Locke (1689) mengatakan bahwa masyarakat sipil merupakan bagian yang terpisah dari pemerintah karena mereka ingin pemerintahmelindungihakmilikpribadi(dikutip dari https//chm gnu Pengertian Pengertian yang diberikan Locke ini mempengaruhi definisi mengenai masyarakat sipil hingga abad ke-18. Pemikiran Locke terutama sangat mempengaruhi pemikiran dan tulisan yang dibuat Adam Ferguson dan Adam Smith. Smith mengemukakan bahwasanya civil society merupakan "economic-men", bagi Sm ith kepentingan individu merupakan sesuatu yang nantinya akan memotivasi pembentukan komunitas masyarakat sipil pada masa-masa awal perkembangannya. Pandangan kedua orang ini dapat dianggap sebagai bagian dari paradigma naturalistik yang bersifat dalam memandang keberadaan civil society (Laine 2014).

Dalam buku Element of The Philosophy of Right (1820), Hegel mengemukakan bahwa masyarakat sipil adalah sebuah "system of need", yaitu sebuah tempat dimana setiap individu berusaha mendapatkan kepentingan pribadinya melalui ekspektasi sosial (catdir.loc.gov/catdir/ samples/cam031.pdf). Menurut Hegel adalah salah menilai dunia yang meng-global berarti menjamin kesemerataan ekonomi juga, malah yang kemudian menyebabkan munculn adalah paham setiap orang untuk dirinya sendiri. SedangkanKarlMarx berpendapatbahwanegara hanyalah konsolidasi politik dari dominasi para kaum borjuis yang terbentuk dalam sebuah masyarakat sipil, hal ini dia utarakan terutama untuk mengkritisi revolusi Perancis, terutama untuk mengkritik prinsip liberty, equality, and fraternity yang diutarakan di 'Declaration of The Rights of Man and The Citizen pada tahun 1789 (Laine 2014). Menurutnya The Right Of Man bukanlah berarti untuk semua individu tanpa kecuali, melainkan hanyalah untuk kaum borjuis saja dan menepikan golongan proletar. Prespektif kiri dalam memandang keberadaan civil society dapat dipandang sebagai kritik terhadap paradidgma naturalistik-liberal yang dijelaskan sebelumnya. Jika paham naturalistik beraanggapan bahwa civil society merupakan konsekuensi yang tidak tereelakkan dari sistem demokrasi, disisi lain prespektif kiri memandang keberadaan civil society merupakan alat masyarakat kaya (pemodal) dalam mencapai kepentingan-kepentingannya.
Dalam kasus Indonesia dan India, menurut penulis, adalah sebuah setting dimana kedua konsep ini bertemu, maksudnya dikedua negara ni demokratisasi dan civil society muncul ebagai sesuatu yang natural sebagaikonsekuens demokratisasi didalam sistem politik, namun dalam proses dan perkembangnya masih jauh dari ideal, dan cenderung bersifat elitis.

Muthiah Alagappa (2004) dalam buku civil society and political change in asia, definisi dan konsep civil society yang dikembangkan di dunia barat, tidak bisa sepenuhnya dipakai dalam konteks masyarakat asia dan amerika latin, disebabkan oleh perbedaan sejarah yang membentuk konsep tersebut. Meskipun begitu, menurut muthiah, penting untuk memaham meskipun ada perbedaan definisi dan konsep ini, namun konsep-konsep mengenai civil society biasanya saling melengkapi satu sama lain. Gurpret Mahajan (2003) dalam kajiannya mengenai civil society di India berpendapat bahwa apa yang masuk ke dalam katagori civi society di India ternyata sarat dengan berbagai katan primordial seperti kasta,suku,agama dan bahasa yang dalam situasi-situasi tertentu dapat memberi ekses negatif pada demokrasi sebagai sistem nilai sehingga memberikan bobo moralnya berbeda dengan konsep civil society barat.

Lalu kemudian mengapa dan bagaimana perbedaan mengenai konsep civil society in terjadi? Menurut penulis, hal ini salah satunya disebabkan oleh faktor yang mendorong kemunculan civil society itu sendiri. Di erop barat pemikiran mengenai masyarakat sipil ni muncul sebagai bentuk perlawanan kaum terepelajar dan filsuf terhadap aristokasi, dominasi gereja dan ketimpangan ekonomi. Oleh karena itu definisi dan konsep civil society di eropa cenderung ideal, utopis dan memiliki batasan yang sangat ketat. Sedangkan pada regional lain seperti Eropa Timur, Asia, dan Amerika latin, kemunculan civil society datang terlambat, dan muncul dari politisi, negarawan atau aktivis pergerakan sebagai reaksi perlawanan terhadap penjajahan atau kekuasaa negara yang menindas.

Dalam civil society and political change in asia (2004), Alagappamenyatakan bahwakonsep civil society eropa yang berasal dari masyaraka yang telah mapan dalam memahami demokras adalah "alien" atau tidak bisa diaplikasikan pada 
masyarakat asia dan amerika latin yang hidup dalam budaya negara atau kekuasaan totalite dalam yang waktu yang panjang. Lebih lanjut menurutnya, karakteristik konsep civil society di negara-negara ini cenderung lebih militan dan pragmatis secara politik. Sebagai sintesa, menurut penulis, keberadaan civil society da perannya terhadap proses demokratisasi di negara-negara asia khususnya seperti India dan Indonesia memilki memiliki ciri khas tersendiri, dan merupakan fenomena yang menarik untuk diteliti secara mendalam karena dapat dipandag sebagai anomali terhadap konsep-konsep barat.

\section{Demokratiasi dan Civil Society di Indonesia} dan India

Sebelum melakukan perbandingan proses demokratisasi dan perbandingan kondisi civi society antara Indonesia dan India, penulis terlebih dahulu akan memberikan deskrips singkat mengenai kedaan umum kedua subjek ini di kedua negara. Seperti yang telah dijelaskan pada bagian sebelumnya, di Indonesia, sejarah demokratisasi dan civil society berkaitan era dengansejarah kekuasaan. Setiap ordekekuasaan (orde lama. baru dan reformasi) memiliki ciri khas tersendiri dalam hal demkoratisasi dan peran civil society dalam proses ini. Dengan tidak menepikan peran sejarah masa lalu, pada bagian ini penulis memfokuskan pembahasan pada periode pasca orde baru yang ditanda dengan jatuhnya kekuasaan diktatoral Presiden Soeharto pada tahun 1998.

Salah satu isu utama dari gerakan reformasi di Indonesia adalah mendorong demokratisas Istilah demokratisasi ini memiliki keterkaitan yang erat dengan konsep-konsep kontempore civil society. Dimana banyak ilmuan politik seperti misalnya Samuel P Huttington, meng anggap bahwa demokratisasi dapat didorong dengan pembangunan sektor civil societ sehingga ketergantungan terhadap partai politik sebagai saluran ide masyarakat dapat dikurangi. Oleh karena itu tidak mengherankan pada masamasa awal setelah berakhirnya kekuasaan orde baru, civil society bertumbuh dengan sangat cepat di Indonesia. Demikan cepatnya hingga akhirnya mengaburkan batas-batas definisi konsep civil society dalam konteks Indonesia itu sendiri.

Sebagai konsekensi berakhirnya kekuasaan orde baru yang begitu dominan, maka kemudian terjadi perebutan kekuasaan oleh kekuatan politik atau bisnis yang berusaha mengisi pos-pos kekuasaan yang kosong setelah ditinggalkan penguasa-penguasa orde baru dan kroninya. Menurut Lee (2012) kondisi ini diperparah dengan tidak tersedianya pemerintahan yang kuat sehingga konflik antar golongan baik yang berbasis ras, agama atau identitas lainnya menajam, sehingga muncu acncaman baru yaitu disintegrasi masyarakat.

Kelemahan pemerintah ini, menurut penulis, kemudian mendorong munculnya civi society-civil society yang menyimpang dan tidak mendukung proses demokratisasi itu sendiri. Lee (2004) mengistilahkan civil society jenis ini sebagai bad civil society atau uncivil society. Istilah uncivil society ini secara sederhana dapa diartikan sebagai organisasi masyarakat, atau civil society yang keberadaannya justru menghambat demokratisasi atau bahkan memicu kon-flik dikalangan masyarakat dan karena alasan-alasan tertentu. Di Indoensia contoh dar uncivil society ini misalnya kelompok-kelompok ekstrimis sgama, preman, dan kelompokkelompok yang eksistensinya terjaga dengan mengkampanyekan kekerasan dan perpecahan dikalangan masyarakat

Pada era reformasi di Indonesia pembenahan demi pembenahan terkait upaya pemberdayaan civil society terus dilakukan. Pembenahan ini dilakukan tidak lepas karena adanya tuntutan dan tekanan yang terus-menerus dar masyarakat sendiri yang mengendaki hak-hak dan ide-idenya dijamin dan "didengarkan" oleh negara. Di samping itu, perubahan struktur kelembagaan politik juga mendorong perubahan-perubahan lain yang terkait dengan hal ini. Adanya perubahan dan redefinisi peran suprastruktur politik (eksekutif, legislatif dan yudikatif) dan juga mekanisme prosedura seperti pemilihan umum yang lebih transparan dan adil. Faktor desentralisasi juga menjadi salah satu perubahan penting dalam tatanan kehidupan sosial politik di Indonesia karena kekuatan dan pergeseran politik di tingkat lokal pun menjadi lebih dinamis. Perubahan kelembagaan dan prosedur di dalam tatanan politik telah menjadi salah satu aspek penting yang terjadi dalam masa demokratisasi di Indonesia dan juga berperan secara signifikan dalam perkembangan civil society terutama dalam tataran regulasi.
Tumbuh dan berkembangnya civil society setelah Orde Baru runtuh menimbulkan sebuah harapan baru yakni munculnya sebuah kekuatan baru dalam mendorong gerakan pembaharuan politik di Indonesia. Pada saat yang bersamaan, struktur politik yang lebih terbuka dan memberi kesempatan yang lebih luas adalah keuntungan kelompok-kelompok civil society di Indonesia pasca reformasi tahun 1998. Tugas civil society dalam konteks ini adalah menghasilkan gagasangagasan yang konstruktif dalam pembangunan dan juga memonitor aparat negara serta kelompok-kelompok ekonomi.

Sebagai sintesa, menurut penulis dalam tiga tahun pertama (era Habibie dan Gus Dur) pemerintah Indonesia dapat dikatakn cukup sukses meciptakan situasi negara yang kondusif untuk memfasilitasi keberadaan civil society. Meskipun kemudian bersamaan dengan itu mucul banyak civil society yang "sakit" atau meminjam istllah Lee (2012) uncivil society, ini dapat dipahami sebagai konsekuensi logis dari kehidupan berdemokrasi, dimana dalam sistem yang demokratis juga akan muncul pihak-pihak yang menentang demokrasi itu sendiri. Sebagai ideologi yang bebas dan terbuka sudah sewajarnya demokrasi juga harus menjamin hak-hak kelompok ini untuk hadir dan ikut serta dalam proses demokrasi itu sendiri.

Meskipun pasca reformasi jumlah civil society secara kuantitas meningkat pesat dan bahkan cenderung tidak bisa dikontrol, hal ini menurut penulis belum bisa dijadikan ukuran kualitas civil society di Indonesia, sebab tidak banyak dari civil society yang eksis saat ini memiliki kemampuan dan memainkan perannya secara ideal dalam sistem politik dem dalam mendorong proses demokratisasi. Kegagalan ini disebabkan oleh banyak faktor seperti tidak mandiri secara ekonomi atau terlibat permainan kekuasaan pada tataran politik praktis, sehingga tidak memiliki sifat yang otonom dari negara dan elit politik. Selanjutnya, pada bagian akhir pembahasan ini penulis akan mendeskripsikan secara singkat proses demokratisasi dan civil society di India.

Demokrasi di India adalah demokrasi yang muncul dari atas. Namun bukan dari kalangan borjuis seperti yang terjadi pada negara-negara Eropa. Demokrasi India, menurut Georg Sorensen peneliti dari universita Aarhus, Denmark (2010), adalah demokrasi yang dicapai melalui koalisi antara elit politik dengan tiga kelompok utama yaitu: 1. profesional perkotaan, yang membangun gerakan kongres, 2. Komunitas pengusaha India dalam bidang Industri dan perdagangan, dan; 3. Para pemilik tanah di pedesaan (elit desa). Sebagai dampaknya, model transformasi demokrasi seperti in (transformasi) seringkali hanya menumbuhkan bentuk demokrasi yang terbatas pada prosedur. Tetapi kelebihannya adalah bahwa bentuk negosiasi elit ini telah mendahului meledaknya partisipasi politik sehingga dapat meminimalisir benturan kekuasaan di kalangan masyarakat. Dikatakan kelebihan karena kondisi ini merupakan kondisi yang ideal dalam konteks transis politik di negara-negara berkembang (Cameron Lowry, 2008:69). Ciri demokrasi ini kemudian mempengaruhi dengan signifikan karakteristik civil society delam proses demokratisasiditndia

Sejak periode 1990-an, yang menandai awaldariliberalisasi, globalisasi dan prosesprivatisasi di India. Pada masa ini terjadi peningkatan interaksi antara masyarakat sipil dan pemerintah yang merepresntasikan negara. Pemerintah India kemudian menyikapi interaksi ini dengan membuat regulasi-regulasi yang ketat terkait dengan pembentukan organisasi masyarakat sipil. Menurut Goswani (2011), melalui aturan-aturan ini Negara mengontrol dengan ketat kemunculan dan arah perkembangan civil society pada masa itu. Dengan demikian, dapat diketahui bahwa civil society di India pada periode ini sangat bergantung pada negara, setidaknya dalam aspek modal ekonomi.

Pada awalnya atau setidaknya sebelum tahun 2007 peregulasian pendanaan civil societ di India sangatlah ketat dalam artian pada masa ini pemerintah India memonopoli pendanaan terhadap civil society. Sebagai akibatnya ketergantungan civil society terhadap pemerintah ada dalam kuadran ektrim, sehingga kemudian mendorong perubahan regulasi. Disebabkan oleh tuntutan masyarakat yang semakin menguat, pada tahun 2007 pemerintah India mengeluarkan paket regulasi baru terkait dengan hubungan civil society dan negara, paket ini kemudian terkenal dengan democratization act. Ada empat hal yang diatur dalam regulasi baru ini, yaitu:

1. Menciptakan sebuah keadaan yang memung-

kinkan civil society agar dapat meningkatkan kinerja mereka dan efektivitasnya, serta melindungi kebebasan dan kemandirian civil society tersebut; 
2. Memberikan legitimasi kepada civil society dalam menerima dan mengelola keuangan yang diberikan oleh pemrintah India dan pihak asing;

3. mengidentifikasi sistem operasi, dimana pemerintah dapat bekerja sama dengan civil society, atas dasar prinsip-prinsip saling percaya dan menghormati, dan dengan berbag tanggung jawab; dan

4. mendorong civil society untuk menerapkan sistem transparansidan akuntabilitas seperti yang diterapkan pada sistem manajemen dan pemerintahan. ( disadur dari Kilby: 2011 \& Goswani :2011)

Diatas kertas paket regulasi ini terlihat sangat menjanjikan bagi kemandirian civil society di India, namun bagitu ternyata pengimplementasian aturan ini masih jauh dari deal. Dalam prakteknya, pemerintah hanya memberi izin pengelolaan dana non pemerintah (terutama dana donor asing) kepada civil society tertentu. Pangkategorian civil society yang berhak mengatur dana non pemerintah kemudian menjadi "permainan" baru elit politik yang merepresentasikan negara dengan civil society. Hal ini kemudian membuat setelah regulasi ini dikeluarkan, menurut penulis, peran civil society dalam demokratisasi di India tidak dapat mencapai titik ideal karena dipakai oleh "negara" yang direpresentasikan elit-elit tertentu untuk kepentingan-kepentingan politik yang bersifat praktis. Dengan kondisi seperti ini, tesis Gurpret Mahajan (2003) yang berpendapat bahwa dalam proses demokratisasi di India, ternyata melahiran organisasi-organisasi masyarakat sipil yang "sakit", situasi yang hampir mirip dengan keadaan di Indonesia.

\section{PENUTUP}

Berdasarkan deskripsi mengenai realitas demokrasi, demokratiasi dan civil society di Indonesia dan India yang deijelaskan pada bagian sebelumnya, dapat dibuat beberapa kesimpulan sebagai berikut. Pertama, kemiripan demografis dan historis membuat proses demokratisasi kondisi civil society di kedua negara memiliki beberapa kemiripan, antara lain, (a) secara kuantitas civil society dikedua negara berkembang drastis, namun kebanyakan tidak atau belum mampu menjalankan perannya dengan ideal, (b) "bonus" demografis dan keberagaman sosio kultural ternyata pada batas-batas tertentu dapat memberi ekses negatif pada proses demokratisasi dan pembangunan civil society, dan (c) proses transisi demokrasi, membuat pembangunan sector civil society cenderung menjadi lahan permainan politik elit-elit yang memiliki modal ekonomi atau politik.

Pada kedua negara ini, proses demokratisas mendorong munculnya fenomena civil society yang "sakit" atau (un)civil society (meminjam istilah Verona bettinnger lee). Keberadaan civi society-cicil society seperti ini sebenarnya merupakan fenomena yang jamak pada negara yang tengah mengalami transisi demokras (biasanya negara berkembang), yang menuru penulis, muncul karena cultural shock yang terjadi ketika kultur konservatif dipaksa menjadi sedikit lebih liberal atau moderat dalam proses demokratisasi. Organisasi masyaraka sipil seperti ini, alih-alih mendorong proses demokratisasi, namun pada batas-batas tertentu, justru dapat menjadi faktor penghambat.

Terakhir, secara teoritis kondisi atau keberadaan civil society di kedua negara ini, menuru penulis dapat disebut sebagai pertemuan antara prespektifnaturalistik yang liberal dan prespektif kiri yang berbasis konflik dalam struktur sosial. Keberadaan dan perkembangan organisasiorganisasi masyarakat sipil di kedua negara muncul secara natural sebagai konsekuensi dari perluasan dan perlindungan hak-hak individu dalam proses demokratisasi, namun disisi lain karena faktor-faktor lain seperti budaya politik, situasi ekonomi, oligarki elit dan lainlain keberadaan civil society dalam proses demokratisasi pada kedua negara ini juga tidak dapat dinikmati semua orang, melainkan masih dikuasai kepentingan-kepentingan bersifat elitis yang menguasai modal politik dan ekonomi.

\section{DAFTAR PUSTAKA}

Alagappa, Muthiah, 2004, Civil Society dan Political Change in Asia, Stanford, Stanford University Press

Budiardjo, Miriam. 2008. Dasar-Dasar Ilmu politik Edisi Revisi. Jakarta: PT. Gramedia

Debika Goswani, Rajesh Tandon, Kaustuv $\mathrm{K}$ Bandyopadhyay. Civil Society in Changing India: Emerging Roles,
Relationships and Strategies. New Delhi. PRIA : 2011.

Mahajaan, Gurpreet, 2003, Civil Society and its Avatar, dalam C.M Elliot (ed.)

Laine, Jussi, 2014, Debating Civil Society: Contested Conceptualizations and Development Trajectories, International Journal of Non-for-Profit Law

Lee Beittinger, Verona (Un)civil Society and Political Change in Indonesia, 2012, New York, Routledge

Lowry, Cameron. Research Assistant For The Asia Pacific Governance and Democracy Initiative $(A G D I)$. Honolulu. East-West Center : 2008

Killby, P. NGOs in India: The Challenges of Women's EmpowermentAndAccountability. New York. Routledge: 2011

\section{Sumber Lai}

Internet Source:http://www.centralchronicle. com/statesshould-follow-suit-forvision-to-ngos-like-mp-gadkari.html Accessed in october, 2016

Internet Source: http://www.defence.pk/ forums/indiadefence/88007-visitsbig-five-leaders-six-months-indicateindia-sgrowing-global-stature.html, Accessed in october, 2016.

perspektif-hegel-marx-dan-gramsci Accessed in October, 2016

http://asiasociety.org/civil-society-indonesia Accessed in October, 2016

https://chnm.gmu.edu/revolution/d/268/, Accessed in October, 2016 